\title{
Spectrum of Public Health Significant and Antibiotic Resistant Microorganisms Isolated from Mobile Phones of Meat and Fish Handlers of Tripura, India
}

\author{
Seuli Saha Roy* \\ Department of Veterinary Public Health and Epidemiology, \\ College of Veterinary Sciences and Animal Husbandry, R. K. Nagar, \\ West Tripura - 799008.Tripura, India \\ *Corresponding author
}

\section{A B S T R A C T}

\section{Keywords}

Mobile phone, Contamination, Handlers, Public health,

Antibiogram, Resistance

Article Info

Accepted:

04 June 2018

Available Online:

10 July 2018
Mobile phone is an extensively used precious integral part of our daily life, increasingly assuming the status of sources of pathogenic organisms for disease transmission. During the present study 150 swab samples were collected from mobile phones of chicken, pork, chevon, fresh and processed fish handlers, and street food venders of Tripura for isolation, identification of public health significant bacteria and its antibiogram. Out of $150 \mathrm{swab}$ sample examined $97.33 \%$ and $40 \%$ mobile phones were found contaminated with pathogenic bacteria and fungi, respectively. $80 \%$ of processed fish handlers mobile phones were highly contaminated with fungi. Mobile phone of pork and processed fish handlers were showed highest and lowest total viable count, respectively. Staphylococcus spp., MRSA, Bacillus cereus, E. coli, Klebsiella spp and Proteus spp. were frequently isolated from all mobile phone users. Among all mobile phone users highest percentage of Staphylococcus spp. (48\%) Staphylococcus aureus (32\%), Klebsiella spp (20\%), Proteus spp. (24\%); Bacillus cereus (56\%), E. coli (32\%), were isolated from the chicken, pork, meat and fish handlers. 23.68\% MRSA isolated from the all selected groups of mobile phone handlers. All the isolates were resistant to Amoxycillin, Ampicillin and Oxytetracycline. The present study emphasized that the mobile phones acts as fomites for spreading of pathogenic microbes for disease transmission.

\section{Introduction}

Today, Mobile phones are undeniable and precious integral part of our daily professional and social life for communications. Mobile phone is an extensively used personal gadget and is usually kept in close contact with the body. It is used for communication by different group of people in every place or situation including perishable food shops, laboratory or clinics. With the invention of 'fully loaded' mobile phones/ smart phone, in addition to the standard voice function, a mobile phone can support many additional services such as SMS, GPS, MMS for sending and receiving photos and videos, data 
processing and access to the internet. In many countries, mobile phones outnumber landline telephones as most adults and many children now owning mobile phones. The availability of cost effective easy access prepaid services, where the subscriber does not have to commit to a long term contract, has helped fuel for growth of cellular subscribers on a massive scale in India. With high level of mobile phone penetration, a mobile culture has evolved, where the phone becomes a key social tool, and people rely on their mobile phone address book to keep in touch with their family and friends. Mobile phones also serve as clocks, organizers, reminders, calculators etc., depending on the mobile phone accessories. Presently, Asia has the rapidest growth rate of cellular phone subscribers in the world.

With all the achievements and advantages of the mobile phone, it is easy to overlook the health hazards arise out of the excessive and unusual use of this item. Furthermore, many mobile phone users do not have regard for their personal hygiene which again aggravated the problems. People from many spheres of life are exposed to this risk due to their negligence or lack of knowledge of dos and don'ts of personal hygiene. They seldom clean their mobiles and often touch them during or after handling of live as well as slaughtered animal, fish and food without or improper hand washing. The constant handling of the phone by users in all places and occasions makes it open for arrays of microorganisms, making it a harbour and a breeding ground for microbes especially those associated with the skin and working environment. The specific features of mobile phones having depressions at the area of key pad and other places make it a heaven of loads of microorganisms. It can carry various potential zoonotic pathogens and become a source of infection and a potential health hazard for self and family members (Gurang et al., 2008). Mobile phones can acts as a fomite for transmission of all sorts of microorganisms (that are normally found in our skin and environment) to the other places and people. It is evident from various research findings that mobile phones can constitute a major health hazard. Further, sharing of mobile phones may directly facilitate the spread of potentially pathogenic microbes to the community (Prescott et al., 2005).

Staphylococcus aureus can cause illnesses from pimples and boils to pneumonia and meningitis and is a close relative of methicillin resistant $S$. aureus (MRSA). The main reservoir of $S$. aureus is the hand from where it is entered into food during handling (Hui et al., 2001). Hand provides as an important vehicle for transmission of various microbes including the Enterobacteriaceae group (Kapdi et al., 2008). They also reported that the microbialload of the hand is extremely complex and variable in nature, consisting of gram positive organisms like $S$. aureus and gram-negative organism like $P$. aeruginosa, which may survive for considerable period of time on the hand and may thus serve either as a reservoir or shelter of infection. S. aureus, Enterococcus feacalis, $P$. aeruginosa, E. coli, Klebsiella spp, Serratia spp, Proteus vulgaris and Bacillus spp were frequently isolated from the mobile phone of health worker, university employees, marketers, food vendors, lecturer, students (Akinyemi et al., 2009; Kilic et al., 2009; Verma et al., 2015; Zakaia et al., 2016; Abdallah, 2017). The main disease burden in the society are communicable diseases like diarrhoea, respiratory diseases and urinary tract infection most commonly caused by $E$. coli, Klebsiella spp, and Staphylococcus spp. Anti-microbial resistance pattern observed among bacteria associated with mobiles phone is also a huge challenge to the commonly available drugs (Pal et al., 2015). According to The WHO one of the world's most serious public health problems is anti-microbial resistance. 
The majority of the population in North- East region is traditionally dependent on livestock for their livelihood and there are no taboos for consumption of meat. It is a common feature to observe that each and every family use to incorporate fresh or processed fish or pork or chicken or chevon in their regular diet. Further, most of the fish are imported from Bengladesh and there is no slaughter house in Tripura.

Till date, there is no report on the status of microbial contamination of mobile phones in Tripura. In the light of these, the present study was carried out to determine the microbes associated with the mobile phones of chicken, pork, chevon, fresh and processed fish handlers, and street food vendor, and the antimicrobial resistance pattern of isolated microbes from the mobile phones in Tripura.

\section{Materials and Methods}

\section{Sample collection}

A total of 150 swab samples, 25 samples from each group were collected randomly from the mobile phones of chicken handlers, pork handlers, chevon handlers, fresh and processed fish handlers, and street food vendor (mainly pork and chicken products seller) using sterile cotton swab from different markets of West Tripura, North-east. The samples were collected in duplicate by rotating the cotton swab stick over the surface of the both sides of mobile phones.

\section{Microbiological study}

Nutrient broth, Nutrient agar, Sabouraud Dextrose Agar (SDA) agar, MacConky agar, Mannitol salt agar, Eosin Methylene Blue agar, Mannitol egg yolk agar and Muller Hinhton agar were used in the present study for isolation of the microbes. The classical culture techniques were used as standard practices for detection of the pathogens from swab samples.

\section{Total viable count}

Total viable count was done as per the guidelines of American Public Health Association (1992) using pour plate method. At first the one set of swab samples were soaked properly in $1 \mathrm{ml}$ of $0.1 \%$ peptone water and after that to get 1:10 dilution $9 \mathrm{ml}$ of $0.1 \%$ peptone water were mixed properly. Thereafter, 10 fold serial dilutions were made upto $6^{\text {th }}$ dilution. $1 \mathrm{ml}$ each from the $10^{3}$ and $10^{4}$ dilutions was inoculated in the presterilized Petri plate. About $15 \mathrm{ml}$ of sterilized nutrient agar maintained at about $45 \pm 1^{0} \mathrm{C}$ was then poured in each Petri plate and were mixed uniformly and allowed to solidify. The plates were incubated at $37^{\circ} \mathrm{C}$ for $24 \mathrm{hrs}$. Average count of the colonies between 30-300 in the $10^{3}$ and $10^{4}$ dilutions was multiplied by the dilution factor to get the total viable bacterial count of the sample.

\section{Isolation and identification}

Another set of the swab samples were soaked in nutrient broth and incubated aerobically at $37^{0} \mathrm{C}$ for $24 \mathrm{hrs}$ for the growth of microorganisms. After that each sample was streaked on the nutrient, mannitol salt, MacConky and Sabouraud Dextrose Agar, and plates were incubated at $37^{\circ} \mathrm{C}$ for $24-48 \mathrm{hrs}$ for the growth of microorganisms.

The microbes were identified on the basis of colony characteristic, Gram's staining, and growth in differential and selective media and by appropriate conventional biochemical tests (Cowan and Steel, 1993).

\section{Antibiotic sensitivity test}

The antibiotic susceptibility was carried out using frequently prescribed antibiotics in the 
locality. The antibiotic discs were selected for the present study includes Methecillin (MET$5 \mathrm{mcg}$ ) Gentamycin (GEN-10mcg), Ofloxacin (OF-5mcg), Amoxicillin (AMX-30mcg), Ampicillin (AMP-10mcg), Oxytetracycline (O-30mcg), Ciprofloxacin (CIP-30mcg), Erythromycin (E-15mcg), Enrofloxacin (EX10mcg) Streptomycin (S-30mcg), Amikacin (AK-30mcg), Chloramphenicol (C-30) (HiMedia).

Fresh culture was used for Antibiotic sensitivity test (AST). Colonies were transferred into $5 \mathrm{ml}$ of Tryptone Soya broth and was incubated at $37^{\circ} \mathrm{C}$ for $5 \mathrm{hrs}$. After that a sterile cotton swab was dipped into the inoculum and the soaked swab was rotated firmly against the upper inside wall of the tube to remove the excess fluid. The entire surface of the Muller Hinhton agar plate was spread properly with the swab. Then the predetermined battery of antimicrobial discs was dispensed aseptically onto the surface of the inoculated plate. Each disc was pressed down to ensure complete contact with the agar surface and was incubated at $37^{\circ} \mathrm{C}$ for $24-48$ hrs. Diameter of the zones of inhibition was measured with a ruler and interpreted using Clinical and Laboratory Standard Institute (CLSI, 2016).

\section{Results and Discussion}

A total of 150 swab samples from mobile phone of chicken, pork, chevon, fresh and processed fish handlers, and street food vendor were randomly studied and $97.33 \%$ mobile phones were found contaminated with microbiota. The highest total viable count (TVC) was observed in pork handlers $\left(4.29 \times 10^{5}\right)$ and lowest in processed fish handlers $\left(2.55 \times 10^{5}\right)$ mobile phones.

The present research findings indicated that Staphylococcus spp, Staphylococcus aureus, Bacillus spp, Enterobacteraece group of bacteria particularly E. coli, Klebsiella spp. and Proteus spp, and fungi were the main isolates frequently associated with the mobile phones of chicken handlers, pork handlers, chevon handlers, fresh and processed fish handlers, and street food vendor.

Gram positive cocci, Staphylococcus spp and Staphylococcus aureus were identified based on morphological characteristic and biochemical tests. On Mannitol salt agar Staphylococcus aureus produced yellow colonies with yellow zones whereas other Staphylococcus spp exhibited small pink or red colonies with no colour change to the medium. Staphylococcus spp was frequently isolated from all groups of mobile phone handlers and the highest rate of contamination was observed in chicken (48\%) and lowest in processed fish handlers (16\%) mobile phones. Staphylococcus aureus was also recorded from all groups of mobile phone handlers and the highest rate of contamination was recorded in pork handlers (32\%), followed by street food vendor (28.57\%), chevon handlers (28\%), chicken and fish (24\%) handler and processed fish handlers $(20 \%)$ mobile phones (Table 1).

Some selected Colonies from nutrient agar were highly motile Gram positive rods and suspected for Bacillus spp. These colonies were further streaked on mannitol-egg yolk agar and incubated at $37^{\circ} \mathrm{C}$ for $24 \mathrm{hrs}$. The distinct flat pink colonies with serrated borders and surrounded by a zone of Lecithinovitellin reaction were taken as Bacillus cereus. Biochemical tests revealed that the isolates were positive for Catalase reaction, citratate utilization, Nitrate reduction, glucose fermentation, Vogesproskauer test and negative for indole, Mannitol and Arabinose, which was characteristic for Bacillus cereus. Bacillus cereus was frequently isolated from the all groups of mobile phone handlers. It was 
predominantly present in the mobile phone of chevon handlers $(56 \%)$ followed by in street food vendor $(42.86 \%)$, pork handlers $(36 \%)$, chicken handlers (24\%), processed fish (20\%) and fresh fish (16\%) handlers mobile phones (Table 1).

Pink (lactose-positive) and cream/off-white (lactose - negative) colonies were observed in MacConkey agar. After that the pink colonies were streaked on EMB agar and were incubated at $37^{\circ} \mathrm{C}$ for $24 \mathrm{hrs}$. The bacteria in EMB agar plate was showed clear metallic shine which indicated the presence of $E$. coli in the sample. Biochemical tests (IMVIC) revealed that the gram negative coccobacilli was motile, positive for indole and methyl red, negative for Voges Proskauer, Citrate utilization, Urease production, $\mathrm{H}_{2} \mathrm{~S}$ production which was specific for E. coli. Among all the mobile phone users highest contamination of E. coli was isolated from the fresh fish handlers $(32 \%)$, and lowest from street food vendor (4.76\%) mobile phone. Second highest contamination of $E$. coli was recorded from the mobile phone of pork handlers (28\%) (Table 1).

Few lactose fermentive colonies did not produced any metallic shine in EMB agar plate but these organism was non motile, negative for indole production, methyl red reaction and $\mathrm{H}_{2} \mathrm{~S}$ production but positive for Voges Proskauer, Citrate utilization, and Urease production which was specific for Klebsiella spp. Klebsiella spp was isolated from three groups of mobile phone handlers with a highest prevalence in pork handlers (20\%) followed by fresh fish handlers (12\%) and lowest in chicken (8\%) and mobile phone (Table 1).

Non lactose fermentive bacteria on MacConky agar were Gram negative, motile, positive for indole production, Methyl red reaction, $\mathrm{H}_{2} \mathrm{~S}$ production and Urease production and negative for Voges Proskauer and Citrate utilization which was typical for Proteus spp. $24 \%$ pork, $20 \%$ fresh fish, $16 \%$ chicken, 9.52\% street food vendor and $4 \%$ chevon handlers phones were carrying Proteus spp (Table 1).

Growth on Sabouraud Dextrose Agar revealed that the mobile phones of processed fish (80\%) handlers were highly loaded with fungi. The prevalence of fungi in mobile phone of chicken handlers, street food vendors, fresh fish and chevon handlers were $44 \% 38.10 \%$, $32 \% 28 \% 24 \%$, respectively.

Antibiotic sensitivity test results revealed that 23.68\% Staphylococcus aureus isolated from the all selected groups of mobile phone handlers was resistant to Methicillin. Most of the Staphylococcus spp. was shown sensitive to Ciprofloxacin, Enrofloxacin, Chloramphenicol and Amikacin.

Isolated Bacillus cereus was also highly sensitive to Ciprofloxacin, Erythromycin, Amikacin, Streptomycin and Chloramphenicol, and moderately sensitive to Enrofloxacin.

E. coli, Klebsiella spp and Proteus spp isolated from different meat, fish and street food vendors mobile phone were highly sensitive to Gentamycin, Ciprofloxacin, Enrofloxacin, Amikacin and Chloramphenicol, and moderately sensitive to Ofloxacin and Streptomycin. All the isolates were highly resistant to Amoxycillin, Ampicillin and Oxytetracycline (Table 2).

The research findings revealed that Staphylococcus spp, Staphylococcus aureus, Bacillus cereus and Enterobacteraece group of bacteria particularly E. coli, Klebsiella spp. and Proteus spp, were the main isolates frequently associated with the mobile phones of chicken, pork, chevon, fresh and processed fish handlers, and street food vendors (Fig. 1 and 2). 


\begin{tabular}{|c|c|c|c|c|c|c|c|c|c|}
\hline \multirow{2}{*}{$\begin{array}{c}\text { Profession } \\
\text { of mobile } \\
\text { phone } \\
\text { holder }\end{array}$} & \multirow{2}{*}{$\begin{array}{c}\text { No. of } \\
\text { sample } \\
\text { screened }\end{array}$} & \multirow{2}{*}{$\begin{array}{l}\text { No. of } \\
\text { Positive } \\
\text { sample }\end{array}$} & \multicolumn{6}{|c|}{$\%$ of isolated bacteria } & \multirow[b]{2}{*}{$\begin{array}{l}\% \text { of } \\
\text { Fungi }\end{array}$} \\
\hline & & & $\begin{array}{l}\text { Staphylo } \\
\text { coccus } \\
\text { spp }\end{array}$ & S. aureus & B.cereus & E.coli & $\begin{array}{l}\text { Klebsiella } \\
\text { spp }\end{array}$ & $\begin{array}{l}\text { Proteus } \\
\text { spp }\end{array}$ & \\
\hline $\begin{array}{l}\text { Chicken } \\
\text { handlers }\end{array}$ & 25 & 25 & 48 & 24 & 24 & 20 & 8 & 16 & 44 \\
\hline $\begin{array}{c}\text { pork } \\
\text { handlers }\end{array}$ & 25 & 25 & 44 & 32 & 36 & 28 & 20 & 24 & 24 \\
\hline $\begin{array}{l}\text { chevon } \\
\text { handlers }\end{array}$ & 25 & 25 & 32 & 28 & 56 & 8 & 0 & 4 & 28 \\
\hline $\begin{array}{c}\text { fresh Fish } \\
\text { handlers }\end{array}$ & 25 & 25 & 44 & 24 & 16 & 32 & 12 & 20 & 32 \\
\hline $\begin{array}{c}\text { process fish } \\
\text { handlers }\end{array}$ & 25 & 20 & 16 & 20 & 20 & 4 & 0 & 0 & 80 \\
\hline $\begin{array}{l}\text { Street food } \\
\text { vendor }\end{array}$ & 25 & 21 & 33.33 & 28.57 & 42.86 & 4.76 & 0 & 9.52 & 38.10 \\
\hline $\begin{array}{c}\text { Overall } \\
\text { prevalence }\end{array}$ & 150 & 146 & $\mathbf{9 7 . 3 3 \%}$ & & & & & & \\
\hline
\end{tabular}




\section{Int.J.Curr.Microbiol.App.Sci (2018) 7(7): 193-204}

\begin{tabular}{|c|c|c|c|c|c|c|c|c|c|c|c|c|c|}
\hline \multirow{3}{*}{$\begin{array}{l}\text { Name of } \\
\text { Different } \\
\text { Isolates }\end{array}$} & \multirow{3}{*}{$\begin{array}{l}\text { No. of } \\
\text { total } \\
\text { isolates }\end{array}$} & \multicolumn{12}{|c|}{ Table. 2 Antibiotic sensitivity patterns of the isolated bacteria from mobile phone of different groups } \\
\hline & & \multicolumn{12}{|c|}{ Name of antibiotic discs (mcg/disc) } \\
\hline & & 氖 & 苞 & 氞 & 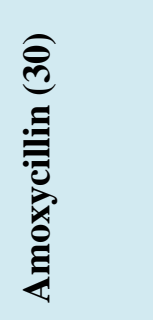 & 氞 & 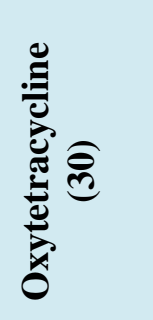 & 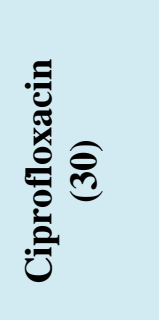 & ( & 氞 & 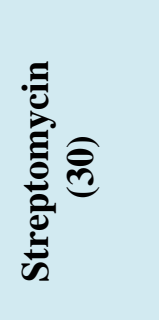 & 远 & 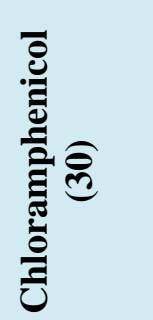 \\
\hline $\begin{array}{l}\text { Staphyloc } \\
\text { occus } \\
\text { spp }\end{array}$ & 53 & $\begin{array}{c}50 \\
(94.34 \%)\end{array}$ & 0 & $\begin{array}{c}19 \\
(35.85 \%)\end{array}$ & $\begin{array}{c}7 \\
(13.21 \%)\end{array}$ & $\begin{array}{c}6 \\
(11.32 \%)\end{array}$ & $\begin{array}{c}11 \\
(20.75 \%)\end{array}$ & $\begin{array}{c}49 \\
(92.45 \%)\end{array}$ & $\begin{array}{c}35 \\
(66.04 \%)\end{array}$ & $\begin{array}{c}46 \\
(86.79 \%)\end{array}$ & $\begin{array}{c}47 \\
(88.68 \%)\end{array}$ & $\begin{array}{c}40 \\
(75.47 \%)\end{array}$ & $\begin{array}{c}44 \\
(83.02 \%)\end{array}$ \\
\hline $\begin{array}{l}\text { Staphyloc } \\
\text { occus } \\
\text { aureus }\end{array}$ & 38 & $\begin{array}{c}29 \\
(76.32 \%)\end{array}$ & 0 & $\begin{array}{c}15 \\
(39.47 \%)\end{array}$ & $\begin{array}{c}5 \\
(13.16 \%)\end{array}$ & $\begin{array}{c}4 \\
(10.53 \%)\end{array}$ & $\begin{array}{c}7 \\
(18.42 \%)\end{array}$ & $\begin{array}{c}30 \\
(78.95 \%)\end{array}$ & $\begin{array}{c}21 \\
(55.26 \%)\end{array}$ & $\begin{array}{c}25 \\
(65.79 \%)\end{array}$ & $\begin{array}{c}26 \\
(68.42 \%)\end{array}$ & $\begin{array}{c}27 \\
(71.05 \%)\end{array}$ & $\begin{array}{c}25 \\
(65.79 \%)\end{array}$ \\
\hline $\begin{array}{l}\text { Bacillus } \\
\text { cereus }\end{array}$ & 47 & 0 & $\begin{array}{c}5 \\
(10.64 \%)\end{array}$ & $\begin{array}{c}22 \\
(46.81 \%)\end{array}$ & $\begin{array}{c}10 \\
(21.28 \%)\end{array}$ & $\begin{array}{c}7 \\
(14.89 \%)\end{array}$ & $\begin{array}{c}12 \\
(25.53 \%)\end{array}$ & $\begin{array}{c}40 \\
(85.11 \%)\end{array}$ & $\begin{array}{c}45 \\
(95.74 \%)\end{array}$ & $\begin{array}{c}35 \\
(74.47 \%)\end{array}$ & $\begin{array}{c}40 \\
(85.11 \%)\end{array}$ & $\begin{array}{c}28 \\
(59.57 \%)\end{array}$ & $\begin{array}{c}38 \\
(80.85 \%)\end{array}$ \\
\hline E.coli & 24 & 0 & $\begin{array}{c}21 \\
(87.50 \%)\end{array}$ & $\begin{array}{c}14 \\
(58.33 \%)\end{array}$ & 0 & 0 & $\begin{array}{c}7 \\
(29.17 \%)\end{array}$ & $\begin{array}{c}23 \\
(95.83 \%)\end{array}$ & $\begin{array}{c}10 \\
(41.67 \%)\end{array}$ & $\begin{array}{c}21 \\
(87.50 \%)\end{array}$ & $\begin{array}{c}11 \\
(45.83 \%)\end{array}$ & $\begin{array}{c}23 \\
(95.83 \%)\end{array}$ & $\begin{array}{c}24 \\
(100.0 \%)\end{array}$ \\
\hline $\begin{array}{l}\text { Klebsiella } \\
\text { spp }\end{array}$ & 10 & 0 & $\begin{array}{c}8 \\
(80 \%)\end{array}$ & $\begin{array}{c}6 \\
(60 \%)\end{array}$ & 0 & 0 & $\begin{array}{c}3 \\
(30.00 \%)\end{array}$ & $\begin{array}{c}9 \\
(90.00 \%)\end{array}$ & $\begin{array}{c}4 \\
(40.00 \%)\end{array}$ & $\begin{array}{c}8 \\
(80.00 \%)\end{array}$ & $\begin{array}{c}5 \\
(50.00 \%)\end{array}$ & $\begin{array}{c}10 \\
(100.0 \%)\end{array}$ & $\begin{array}{c}8 \\
(80.00 \%)\end{array}$ \\
\hline $\begin{array}{l}\text { Proteus } \\
\text { spp }\end{array}$ & 18 & 0 & $\begin{array}{c}16 \\
(88.89 \%)\end{array}$ & $\begin{array}{c}9 \\
(50 \%)\end{array}$ & 0 & 0 & $\begin{array}{c}5 \\
(27.78 \%)\end{array}$ & $\begin{array}{c}16 \\
(88.89 \%)\end{array}$ & $\begin{array}{c}7 \\
(38.89 \%)\end{array}$ & $\begin{array}{c}15 \\
(83.33 \%)\end{array}$ & $\begin{array}{c}8 \\
(44.44 \%)\end{array}$ & $\begin{array}{c}17 \\
(94.44 \%)\end{array}$ & $\begin{array}{c}15 \\
(83.33 \%)\end{array}$ \\
\hline
\end{tabular}


Fig.1 Distribution of total numbers microbes isolated from the mobile phones

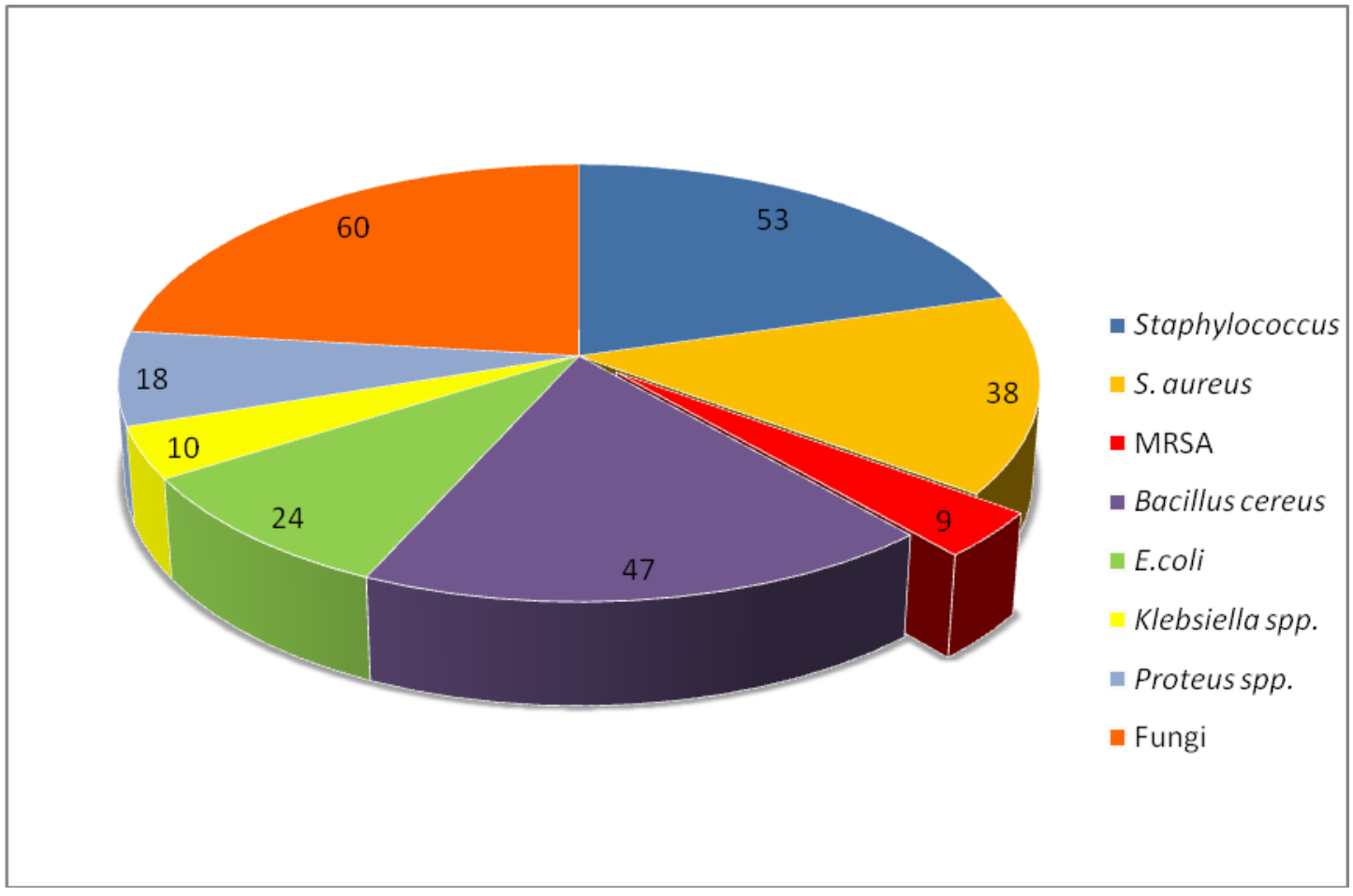

Fig.2 Distribution of various bacterial isolates from mobile phones of different groups

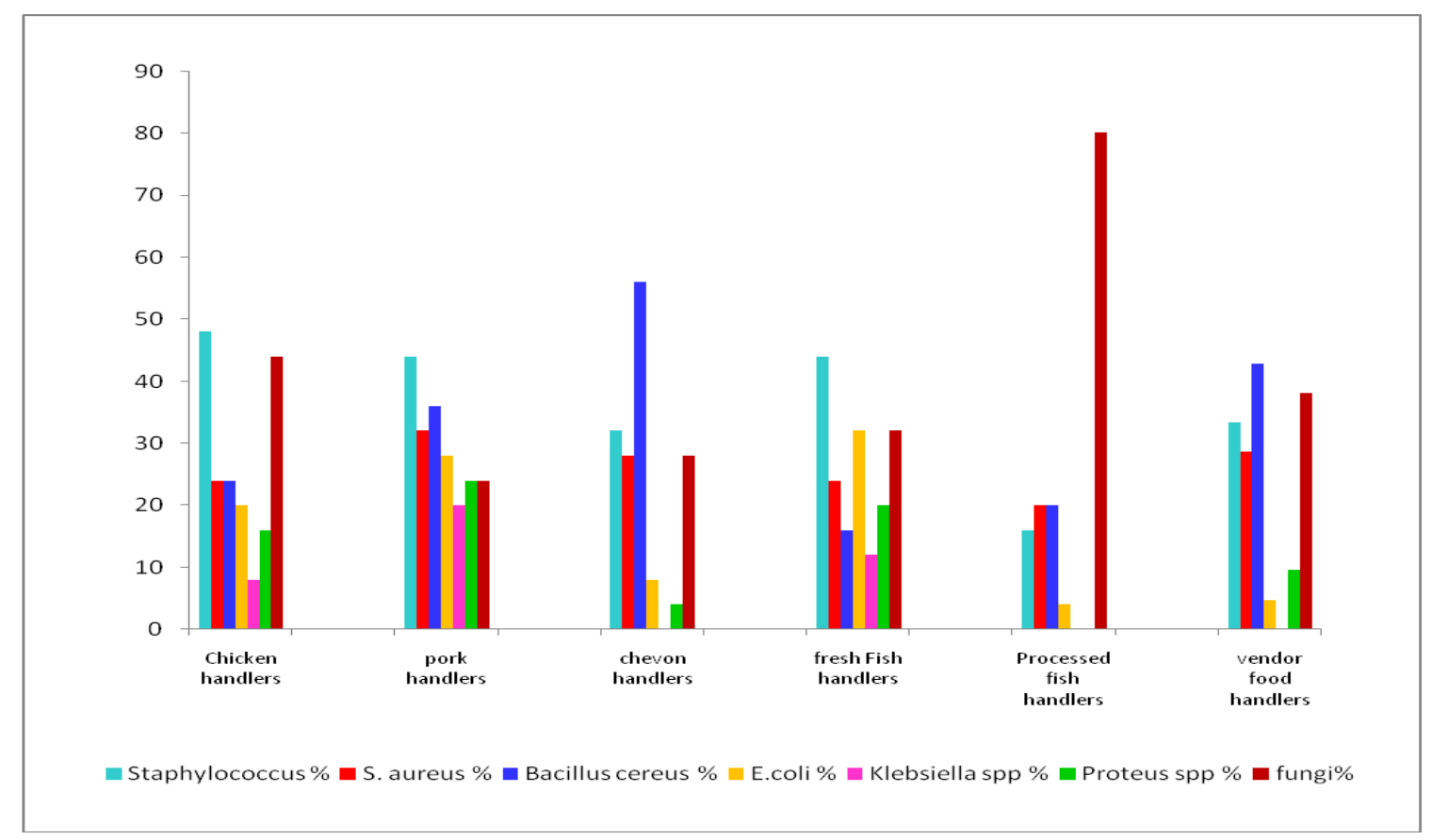


The overall contamination of mobile phone was $97.33 \%$. Highest total viable count was observed in pork handlers and lowest in processed fish handlers mobile phone. TVC is immediately represent the level of contamination of the mobile phones which is undesirable and indicate poor personal hygiene. The results are in accordance with the finding of Bhat et al (2011) who observed that $99 \%$ of the mobile phones of healthcare workers were contaminated with pathogenic micro-organisms and Multi drug resistant bacteria. Healthcare workers Mobile phone in Turkey and India were contaminated with microorganism with a prevalence of $95.5 \%$ and $81.80 \%$, respectively (Ulger et al., 2009; Pal et al., 2015). In Nigeria the public phones were frequently contaminated with $S$. aureus, Bacillus substilis and Enterobacter aerogenes and the mean bacterial viable count of these public phones was $4.93 * 10^{6} \mathrm{CFU} / \mathrm{g}$ on nutrient agar, $2.12 * 10^{6} \mathrm{CFU} / \mathrm{g}$ on MacConkey agar and $3.22 * 10^{6} \mathrm{CFU} / \mathrm{g}$ on Mannitol salt agar (Ekrakene and Igeleke, 2007).

Staphylococcus spp., S. aureus, B. cereus, E. coli, Klebsiella spp and Proteus spp. were frequently associated with the mobile phone of chicken, pork and fresh fish handlers. The higher prevalence of microbiota in the mobile phones of pork, chicken and fresh fish handlers could be accredited to the poor hygienic and sanitary practices associated with the low level of education. The reasons of contamination of mobile phones mainly due to selected groups of people do not wash their hands properly after handling fish, meat and animals. In addition, the water used for washing of hands, meat and fish itself may be a source of E. coli and other Enterobacteriaceae group of organism (Steven et al., 2014; Bordoloi et al., 2014). In meat (chicken, pork and chevon) handlers close proximity of human and animals results in rapid transmission of microbes from animal to handlers. Fish of different water bodies were mostly contaminated with E. coli, Proteus spp., Klebsila spp, B. cereus, Streptococcus spp and Staphylococcus spp (Bhat, 2011) and these organisms were transmitted to the mobile phone through handlers. E coli $(43.9 \%)$ has been the predominant organism followed by Enterococcus faecalis (21.4\%), K. pneumoniae (11.8\%), S. aureus $(10.3 \%)$ isolated from urinary tract infection in Tripura (Debnath et al., 2014; Das et al., 2018). The results are in well corroborating with the findings of Ilusanya et al., (2012) who isolated S. aureus (50\%), Streptococcus faecium (34\%), B. cereus $(32 \%)$, E. coli (26\%), Micrococcus luteus (10\%) from food vendors in Nigeria were. The chicken, pork, chevon, fish handlers and street food vendors did not wash their hands properly before eating or drinking or after going to the toilet which is the predominant cause of mobile phone contamination.

The research findings confirmed that the mobile phones acts as fomite in transmission of disease for human and can serve as vehicle for cross-transmission of microbiota. The findings are in accordance with the observation of others workers. Healthcare workers (doctors, nurses, laboratory technicians, midwives and cleaners) mobile phones were contaminated with $S$. epidermidus, Coagulage negative Staphylococcus spp., S. aureus, MRSA, Bacillus spp., E. coli Acinetobacter species, K. pneumoniae, Pseudomonas species and Enterococcus species. (Kilic et al., 2009; Ulger et al., 2009; Pal et al., 2015; Aisha et al., 2015; Selim and Abaza, 2015). According to Akinyemi et al., (2009) mobile phone served as vehicles for transmission of both hospital and community acquired bacterial diseases. They observed that the mobile phone of marketers, food vendors, lecturers, students, public servants and hospital workers were contaminated with $S$. aureus, E. feacalis, $P$. aeruginosa, E. coli and Klebsiella spp. 
Rusin et al (2002) documented that hand-tomouth transfer of microbes after handling contaminated fomites during casual activities. During every phone call the mobile phones come into close contact with strongly contaminated human body areas with hands to hands and hands to other areas (mouth, nose, ears).

Higher prevalence of fungi recorded from mobile phone of all selected groups may be due to favorable hot and humid weather which is most suitable for the growth of fungi in Tripura. The results are in agreement with the finding of AI-Abdalall, 2010 and Ilusanya et. al.2012. AI- Abdalall, 2010 isolated Alternaria alternata (29.07\%), Aspergillus Niger (26.74\%), Cladosporium sp (20.93\%), Penicillium spp. (10.47\%), Aspergillus flavus (6.98\%), Rhizopus stolonifer and Aspergillus fumigates (2.33\%) from Dammam in eastern Saudi Arabia. Whereas, 24\% Penicillium notatum, 16\% Aspergillus fumigatus, 14\% Aspergillus niger, 14\%Mucor sp. and 4\%Aspergillus flavus were reported from food vendors in Nigeria (Ilusanya et al., 2012). These funguses mainly produce toxins which can be extensively induced food spoilage and food infection.

However, information on microbial contamination of mobile phones of chicken, pork, chevon and fish handlers, and street food vendor in Tripura is not available so no comparison could be possible with the findings of the present study. Most of the mobile users were frequently used their mobile phones during handling of chicken, pork, animals, fish and also during processing of food. The microbes isolated from the present study have been shown to survive on inanimate surfaces for months. Therefore the personal item like mobile phone used by chicken handlers, pork handlers, chevon handlers, fresh and processed fish handlers, and street food vendors can be a continuous source of transmission of microbes.
All the isolates were highly resistant to Amoxycillin, Ampicillin and Oxytetracycline (Table 2). The Antibiotic resistance of the isolated bacteria was due to indiscriminant use (misuse, overuse, self medication etc.) of antibiotic in animals, fish farm as well as in humans who generally do not complete the dose of antibiotics prescribed by physician. The results of the present studies are in accordance with the findings of Bhat et al (2011) and Pal et al 2015 who isolated MRSA, MDR Acinetobacter, and commonly used antibiotic resistant $E$. coli, $K$. pneumonia, E. faecalis, and $P$. aeruginosa. MRSA, ceftazidime resistant Gram negative bacteria, Cephalothin and amoxicillin resistant Staphylococcus epidermidis, were also isolated from mobile phones of healthcare personnels (Gunasekara et al., 2009; Sepehri et al., 2009; Ulger et al., 2009). In Tripura majority of the uropathogens and pus forming microbes like E. coli, Klebsielle spp., Pseudomonus spp. and S. aureus had already developed resistance to most commonly used antibiotics like Cotrimoxazole, Amoxycillin-clavulanic acid, Ciprofloxacin etc. (Debnath et al., 2014; Jamatia et al., 2017; Das et al., 2018).

In conclusion, the present study revealed that significant numbers of pathogenic microbes were isolated from the mobile phones of meat handlers, fish handlers and street food vendors. The results also emphasize that mobile phones may play as a fomites for spreading of pathogenic microbes for disease transmission. Even it could be a vehicle for the spreading of biological weapon for mass devastation if proper care is not been taken. Due to low awareness among the general people like, meat handlers, fish handlers and street food vendors, personal items like mobile phone is infrequently disinfected but extensively used in everywhere even in lavatories environment. Simple measures like proper hand hygiene practices and regular cleaning of the mobile phones with alcohol 
may reduce the risk. Hence, it is concluded that there is an urgent need to aware common people about the potential role of mobile phones in transmission of pathogens. Regular surface disinfection of personal items can decrease transmission of pathogenic microorganism in the healthy family members.

\section{References}

Akinyemi, K.O., Atapu, A.D., Adetona, O.O. and Coker, A.O. 2009. The potential role of mobile phones in the spread of bacterial infections. J. Infect. Dev. Ctries. 3(8):628-632.

Al-Abdalall, A.H. 2010. Isolation and identification of microbes associated with mobile phones in Dammam in eastern Saudi Arabia. Journal of Family and Community Medicine. 17(1):11-4. doi: 10.4103/1319-1683.68783.

Aisha, M. A. S., Khalifallah, H. M. and Elham M. A. S. 2015. Bacterial contamination of Mobile phones and Hands of Health care workers in Sabha Medical Center Hospital, Fazzan Area in Southwestern of LIBYA. International Journal of Current Research on Medical Science 1(4): $1-8$.

Bhat, S.S., Hegde, S.K. and Salian, S. 2011. Potential of Mobile Phones to Serve as a Reservoir in Spread of Nosocomial Pathogens. Online Journal Health and Allied Sciences.10(2):14-18.

Bordoloi, R., Muzaddadi1, A. U. and Ganguly S. 2014. Sanitary Condition of Battala Fish Market at Agartala, Tripura and its Public Health Significance International Journal of Current Microbiology and Applied Science. 3(3): 176-181

Clinical and Laboratory Standards Institute. (CLSI). 2015. M100-S25 Performance Standards for Antimicrobial Susceptibility Testing: Twenty-Fifth Informational Supplement. Wayne, PA.

Cowan and Steel's 1993. Manual for the Identification of Medical Bacteria. 3rd edn. Ed GI Barrow, RKA Feltham Cambridge University Press. Pp 331. ISBN 0-521-32611-7

Das,U. K., Bhattacharjee, P., Debnath, S., Chakraborty, M., Ghosh, R., Das, L. and Chakraborty D. 2018. Antibiotic sensitivity pattern of bacterial isolates from urine samples of admitted patients with urinary tract infection in a tertiary care teaching hospital of Tripura, India: a hospital record based study. International journal of basic and clinical pharmacology. 7(4) DOI: http://dx.doi.org/10.18203/2319-2003. ijbcp20181013

Debnath, J., Das, P. K., Debnath, M. and Haldar K.K. 2014. Aetiological Profile and Antibiotic Susceptibility Pattern in Patients with Urinary Tract Infection in Tripura. Journal of Clinical and Diagnostic Research. 8(8): DL01DL02.

Ekrakene, T. and Igeleke, C.L.2007. Microorganisms Associated with Public Mobile Phones along Benin-sapele Express Way, Benin City, Edo State of Nigeria. Journal of Applied Sciences of Research. 3(12): 2009-2012.

Gunasekara, T.D.C.P., Kudavidanage, B.P., Peelawattage, M.K., Meedin, F., Guruge, L.D., Nanayakkara, G., Nanayakkara, M. and Fernando, S.S.N. 2009. Bacterial contamination of anaesthetists hands, personal mobile phones and wrist watches used during theatre sessions. Sri Lankan Journal of Anaesthesiology 17(1): $11-15$.

Gurang, B., Bhati, P., Rani, U.,Chawla, K., Mukhopodhyay, C. and Barry, I. 2008. Do mobiles carry pathogens. Microcon. Oct.

Hui, Y.H., Sattar, S.A., Murrell, K.D., Nip, W.K. and Stanfield, P.S. 2001. Food borne disease handbook. $2^{\text {nd }}$ Ed., Vol.2 Viruses, parasites, pathogens and HACCP. New York.

Ilusanya, O.A.F., Adesanya, O.O., Adesemowo, A. and Amushan, N.A. 2012. Personal Hygiene and Microbial Contamination 
of Mobile Phones of Food Vendors in Ago-Iwoye Town, Ogun State, Nigeria. Pakistan Journal of Nutrition, 11: 276278. DOI: 10.3923/pjn.2012.276.278

Jamatia, A., Roy, D., Shil, R. and Prabhakar P. K. 2017. Bacteriological profile and antimicrobial resistance patterns isolates in pus samples at Agartala Government Medical College. Asian journal of pharmaceutical and clinical research.10(1):335-337.

Kapdi, M., Hoskote, S. and Joshi, S.R. 2008. Health hazards of mobile phones: an Indian perspective. Journal of Association of Physicians India. 56:893897.

Kilic, L.H., Ozaslan, M., Karagoz, I.D., Zer, Y. and Davutoglu, V. 2009. The microbial coonisation of mobile phone used by healthcare staffPakistanhan Journal of Biological Science. 12(11):882-884.

Pal, S., Juyal, D., Adekhandi, S., Sharma, M., Prakash, R., Sharma, N., Rana, A. and Parihar, A. 2015. Mobile phones: Reservoirs for the transmission of nosocomial pathogens. Advance Biomedical Research. 4: 144. doi: 10.4103/2277-9175.161553

Prescott, L.M., Harley, J.P. and Klein, D.A. 2005. Microbiology. 6th edn. Tim McGraw-Hill co. New Delhi, pp: 675681.

Rusin, P., Maxwell, S. and Gerba, C. 2002. Comparative surface-to-hand fingertip to-mouth transfer efficiency of grampositive bacteria, gram negative bacteria and phage. Journal of Applied Microbiology. 93: 585-592.

Selim, H. S. and Abaza A. F. 2015. Microbial contamination of mobile phones in a health care setting in Alexandria, Egypt. GMS. Hygiene and Infection Control. 10:1-9.

Sepehri, G., Talebizadeh, N., Mirzazadeh, A., Mir-shekari, T. and Sepehri E. 2009. Bacterial Contamination and Resistance to Commonly Used Antimicrobials of Healthcare Workers' Mobile Phones in Teaching Hospitals, Kerman, Iran. American Journal of Applied Sciences 6 (5): 806-810.

Steven, P., Yates, M.V., Williams, D., Chalmers, R. and Gray, N.2014. Microbiology of Waterborne Diseases (Second Edition), Pp. 89-117.

Ulger, F., Esen, S., Dilek, A., Yanik, K., Gunaydin, M. and Leblebicioglu, $\mathrm{H}$. 2009. Are we aware how contaminated our mobile phones with nosocomial pathogens? Annals of Clinical Microbiology and Antimicrobials. 6:78.

Verma, D. K., Barasa,A., Dara,D., Medehen, H. W., and Asrat, H., Demissie,N., Tegenaw, K., Sendeku W. and Berhane, N. 2015. Isolation and characterization of bacteria from mobile phones of students and employees at university of Gondar, Ethiopia. Bulletin of Pharmaceutical Research., 5(3):96-100.

Zakaia, S., Mashatb, A., Abumohssinb, A. M., Samarkandib, A., Almaghrabib, B., Barradahb, H. and Jiman-Fatani, A. 2016. Bacterial contamination of cell phones of medical students at King Abdulaziz University, Jeddah, Saudi Arabia Journal of Microscopy and Ultrastructure 4:143-146.

\section{How to cite this article:}

Seuli Saha Roy. 2018. Spectrum of Public Health Significant and Antibiotic Resistant Microorganisms Isolated from Mobile Phones of Meat and Fish Handlers of Tripura, India. Int.J.Curr.Microbiol.App.Sci. 7(07): 193-204. doi: https://doi.org/10.20546/ijcmas.2018.707.024 